\title{
Prevalence of oral habits in homeless children under care of Yayasan Bahtera Bandung
}

\author{
Gildasya*, Eriska Riyanti** and Syarief Hidayat** \\ * Student \\ ** Department of Pediatric Dentistry \\ Faculty of Dentistry Padjadjaran University \\ Bandung - Indonesia
}

\begin{abstract}
Oral habits, comprising of thumb and lip sucking, lip and nail biting, tongue thrusting and mouth breathing are commonly caused by disturbance in mental development. These persistent habits may lead to disturbance in physical growth, causing disorders such as malocclusion. Homeless children are prone to this condition. The purpose of this descriptive research was to present the prevalence of oral habits in homeless children under care of Yayasan Bahtera Bandung, by survey technique. The sample consisted of 92 children collected by purposive sampling. This research was conducted through interviews and clinical examnations of the oral cavity to elucidate signs of oral habits. The result showed 50\% of homeless children performed oral habits, consisting of 26 boys (55,32\%) and 20 girls (44.44\%). The prevalence of thumb sucking habit was $21.74 \%$, lip sucking or biting was $17.37 \%$, tongue thrusting was $4,35 \%$, nail biting and mouth breathing tied at 3,26\%. The research concluded that a part of homeless children had oral habits, with boys as slight majority, and thumb sucking was the most performed.
\end{abstract}

Key words: oral habits, homeless children

Correspondence: Gildasya, c/o: Mahasiswa Sarjana Kedokteran Gigi Fakultas Kedokteran Gigi Universitas Padjadjaran. Jln. Sekeloa Selatan No.1 Bandung 40133, Indonesia.

\section{INTRODUCTION}

Children's physical growth and mental development is influenced by surrounding social environment. Family holds the biggest role in shaping children's personality. Correct education applied by parents helps children facing their future environmental challenges. Parents' mistakes, especially the mother's, during educating and caring for their children will later cause asocial, physically and mentally pathologic children. ${ }^{1}$ Intestinal colic, facial twitching and persistent habits such as bed wetting, thumb sucking and eating disorders are often the cause of parents' -especially mothers'- incompetence in caring for their children, such as parent-child relationship disharmony, insufficient pleasure during oral phase, early breast-feeding cessation, emotional disturbances, anatomical malformation and diseases. ${ }^{1,2,3}$

A habit is defined as automatic repetitive action as a result of complex natural process involving muscle contraction. ${ }^{2}$ Normal habits may serve as constructive dentofacial function and hold an important role in normal facial growth and occlusal physiology. In contrary, abnormal habits may promote disturbances in dentofacial growth pattern. On the more specific definition, every habit that cause abnormal stress on dentofacial structure which allow a malformation of a structure and inter-structural connection, is defined as a bad habit, and also referred to oral habit. 5
Oral habit is a repetitive action which provokes disorders in teeth and the surrounding supportive tissues, such as thumb and lip sucking, lip and nail biting, tongue thrusting and mouth breathing. ${ }^{2,6}$ These habits are normally temporary, but may also be persistent as the children grow older, causing oral structure growth disturbance which may lead to local disorders such as malocclusion. ${ }^{7}$ Oralhabit-induced malocclusion is dependent on the frequency, intensity and duration of habit action.

Homeless children are a pathetic image of nation's generation. Children are normally related to laughter, games, carefree-ness and problem-less. Reality proves that beautiful childhood does not apply to every individual. Some children, like the homeless ones, are already forced to work for living at relatively infant age. These children are the product of economic issues, broken homes, parental divorce and parent-child relationship disharmony. Environmental harassment with lack of family protection is their expected and ordinary threats. Many studies report that lack of protection against life's cruelness may cause severe damage in children's personality development. 8,9

According to the references on homeless children, these individuals are victims of family harassment who are forced to leave their families. Although the cruel life on the street appears to give more promises than the cruel life in their family, homeless children still long for parents' love and care, especially from a mother. Instead, they must face the cruel street life which obliges them to earn living by 
begging, singing, selling small stuffs et cetera, to provide their basic needs. They often call a day with empty stomach, causing insufficient nutritional intake. ${ }^{9}$

During the pilot survey, the researcher revealed oral habit phenomenon among the population of homeless children. This manifestation is probably caused by bad treatment from their original family, lack of parents' love, emotional disturbance and famine. There has not been any study on the oral habits prevalence in homeless children, so the researcher wanted to elucidate the prevalence of the manifestation among the homeless children under care of Yayasan Bahtera Bandung, age ranging from 6 to 12 years old. This research may serve as a raw data for further planning on oral health development, especially in preventing oral habits in homeless children, which may later increase the national level of oral health.

\section{MATERIALS AND METHODS}

The study was assessed by descriptive method with survey technique. Research population consisted of homeless children under care of Yayasan Bahtera Bandung. Ninety-two samples matching the criteria of homeless children under care of Yayasan Bahtera Bandung, between 6-12 years old, agreed to participate in the study (informed consent) and cooperative, was taken by purposive sampling technique, consisting of 47 boys and 45 girls.

Instruments and materials used in this study were oral mirrors, semilunar explorers, pincers, alcohol, cotton rolls, masks, gloves, flashlights, informed consent forms, questionnaire sheets and writing instruments. Research was assessed questionnaire-guided interview, which was followed by clinical examination to observe the lesions on the oral soft and hard tissue which were probably cause by oral habits. The collected data was later summarized in tables and diagrams of percentage.

\section{RESULTS}

The research conducted on 92 homeless children under care of Yayasan Bahtera Bandung, age ranging from 6-12 years old resulted in:

The result showed that $50 \%$ of the homeless children population had oral habits, while the other $50 \%$ did not (Table 1).

Table 1. Prevalence of oral habits in homeless children

\begin{tabular}{lcc}
\hline & Amount (n) & $\begin{array}{c}\text { Prevalence } \\
(\%)\end{array}$ \\
\hline Practicing oral habits & 46 & 50,00 \\
Not practicing oral habits & 46 & 50,00 \\
\hline
\end{tabular}

Both sex types have equal risks in practicing oral habits. The study showed that the prevalence is higher in boys $(55.32 \%)$ than in girls $(44.44 \%)$ (Table 2$)$.

Table 2. Prevalence of oral habits in homeless boys and girls

\begin{tabular}{lcc}
\hline \multicolumn{1}{c}{ Sex } & Amount (n) & Prevalence (\%) \\
\hline Male & 26 & 55.32 \\
Female & 20 & 44.44 \\
\hline
\end{tabular}

Actions defined as oral habits in this study are finger sucking, lip sucking or biting, tongue thrusting, nail biting and mouth breathing. The result showed finger sucking in the highest position $(43.48 \%)$ while mouth breathing and nail biting tied in the lowest position $(6.52 \%)$.

\section{DISCUSSION}

Kharbada $^{10}$ reported that $25.5 \%$ of school children in Delhi practicing oral habits. Children in this range of age are on the phase of learning to control their emotion. Emotional disturbance such as lack of care and love with too much fear and anxiety is a factor to oral habits. ${ }^{7,11}$ Research showed the prevalence of this action in homeless children under care of Yayasan Bahtera Bandung is 50\% (Table 1), showing that a part of homeless children adopt thus habit. In homeless children, oral habits occur as a manifestation of several factors. The most striking factor is the insufficiency of basic needs, e.g. food, clothing and home, provided by their parents. Questionnaire showed that $76.09 \%$ of population only had one meal per day, therefore oral habits such as sucking was adopted. According to Sigmund Freud, oral activity can give sufficient pleasure to distract children from hunger. ${ }^{1,3}$

According to Gunarsa, ${ }^{3}$ disharmony between children and parents is also a factor to the adoption of oral habits. This study confirmed the theory by the interview results $69.57 \%$ of homeless children admitted of being afraid to their parents, because they are often angry when their children failed to earn sufficient money. These children often serve as victims of their parents' anger and frustration towards life burden. This causes a disharmonic parent-child relationship. Oral habits are often performed after children being punished or grounded.

Table 2 showed that homeless boys had bigger prevalence of oral habits than girls (55.32\% to $44.44 \%$ ). According to Massler, oral habits in boys are more persistent in longer period than girls because boys tend to openly fight against family's or surrounding society's rules than girls, including when they are told to stop practicing oral habits..$^{9,12,13}$

This research defined oral habits as finger sucking, lip sucking or biting, tongue thrusting, mouth breathing and 
nail biting. Finger sucking is a very common oral habit in children, and as shown in table 3 and figure 1, finger sucking held the topmost position $(43,48 \%)$. Cumley stated that persistent finger sucking habit until over 4 years old suggests the presence of emotional disturbance, leading children to suck their fingers to obtain pleasure. ${ }^{14}$ Finger sucking is also performed when feeling insecure to attract attention after being punished or yelled at. ${ }^{5,15}$ Most homeless children performed this action as a manifestation of insecure feeling and fear against anger and punishment.

Tabel 3. Types of oral habits performed in homeless children

\begin{tabular}{lcc}
\hline \multicolumn{1}{c}{ Oral habit types } & $\begin{array}{c}\text { Amount } \\
(\mathrm{n})\end{array}$ & $\begin{array}{c}\text { Prevalence } \\
(\%)\end{array}$ \\
\hline finger sucking & 20 & 21,74 \\
lip sucking or biting & 16 & 17,39 \\
tongue thrusting & 4 & 4,35 \\
nail biting & 3 & 3,26 \\
mouth breathing & 3 & 3,25 \\
\hline
\end{tabular}

Oral habits may cause disorders on teeth and supportive tissues, depending on intensity or how often the action is performed, frequency or how often the action is repeated per day, and duration or how long the action has been performed. ${ }^{7}$ Malocclusions present as anterior open-bite, anterior protrusion, anterior-posterior cross-bite, hightapered palate and crowded dentition may be caused by finger sucking, tongue thrusting and mouth breathing. Clinical examination of the homeless children showed that those habits had caused disorders in dentofacial structures as mentioned and also oral soft tissue disorders such as abnormal dentition marking on the labial and buccal mucosa. According to McDonald and Avery, ${ }^{14}$ there is a relevancy between class II malocclusion and finger sucking habit in various ages. Malocclusions increase from $21.5 \%$ at the age of 3-4 years old to $41.9 \%$ at the age of 12 years old. Malocclusions increase when habit duration increases. Studies reported that effect on the occlusion is temporary when habits are controlled and stopped before 6 years of age. Interview result showed that homeless children of 6 to 12 years of age performed oral habits for over than 1 year period of time with more than once a day frequency as it helps to provide pleasure and convenience.

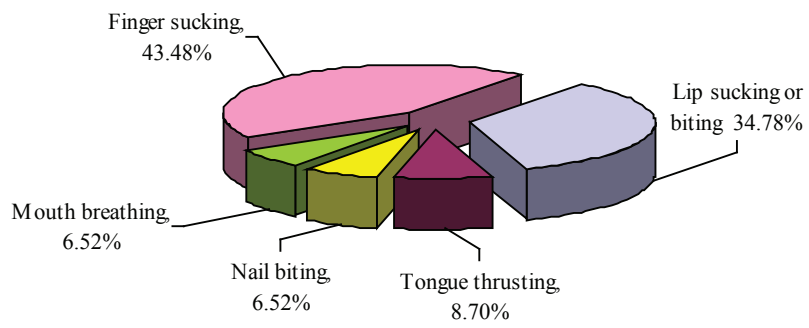

Figure 1. Prevalence of various oral habits in street children.

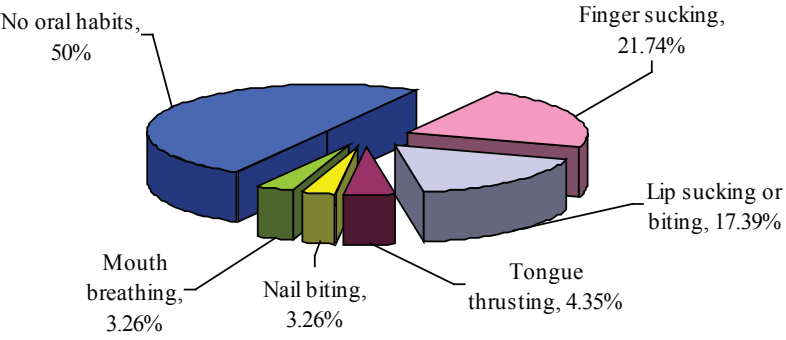

Figure 2. Distribution of various oral habits in street children.

\section{ACKNOWLEDGMENT}

The researcher would like to thank the Principal of Yayasan Bina Sejahtera Indonesia (Bahtera), Field Coordinator, and all the children participating in the research.

\section{REFERENCES}

1. Kartono K. Psikologi anak (Psikologi Perkembangan). Bandung: Mandar Maju; 1995. p. 44-7.

2. Finn SB. Clinical pedodontics. $4^{\text {th }}$ ed. Philadelphia, London and Tokyo: WB Saunders Company; 2003. p. 310-9.

3. Gunarsa SD. Perkembangan psikologi anak dan remaja. Jakarta: BPK Gunung Mulia; 1983. p. 9-10, 43-4, 50-1.

4. Dorland WA, Newman. Kamus Kedokteran Dorland. Edisi ke-29. Huriawati Hartanto, dkk. Jakarta: Penerbit Buku Kedokteran EGC; 2002.

5. Moyers RE. Handbook of orthodontics. $4^{\text {th }}$ ed. Chicago, London, Boca Raton: Year Book Medical Publ; 1988. p. 152-6.

6. Boucher CO. Current clinical dental terminology. $2^{\text {nd }}$ ed. St Louis: The CV Mosby Co; 1974. p. 182.

7. Christensen J, Henry W Fields, Adair SM. Oral habits. In: Pinkham JR, editor. Pediatric dentistry infancy through adolescence. $4^{\text {th }}$ ed. Philadelphia: Elsevier Saunders; 2005. p. 431-7, 470.

8. Terloit AJ. Konsep diri anak jalanan usia remaja yang mengalami abuse dan tidak mengalami abuse. Skripsi. Depok: Fakultas Psikologi Universitas Indonesia; 2001. Available from: URL:http//www. kompas.com/compas-cetak/0507/23/swara/1916829.htm. Accessed July 23, 2005.

9. Irwanto dkk. Anak yang membutuhkan perlindungan khusus di indonesia: analisis situasi. Jakarta: PKPM Unika Atma Jaya Jakarta, Departemen Sosial, UNICEF; 1999. h. 99-113.

10. Kharbanda OP, Sidhu SS, et al. Oral habits in school going children of Delhi: a prevalence study. J Indian Soc. Pedodontics Prevention Dentristry 2003; 21(3):120-4.

11. Graber TM. Orthodontics principles and practice. $2^{\text {nd }}$ ed. Philadelphia, London and Tokyo: WB Saunders Company; 1970. p. 296-313, 628-91.

12. Massler M. Oral habits : development and management. The Journal of Pedodontics 1983; 7(2):109-19.

13. Polyakov E. Digit sucking before the age 4.5: interpretation and some management considerations. International Pediatrics 2002; 17(4): 203-8.

14. McDonald RE, DR Avery. Dentistry for the child and adolescent. $6^{\text {th }}$ ed. St Louis: The CV Mosby Co; 1994. p. 776-84.

15. Foster TD. Buku ajar ortodonsi. Edisi ketiga. Lilian Yuwono. Jakarta: Penerbit Buku Kedokteran EGC; 1997. p. 110-3. 